\title{
Penggunaan Gadget Terhadap Perilaku dan Intensitas Komunikasi Keluarga (Studi Kasus Kecamatan Soreang Kota Parepare)
}

\author{
A. Nurul Mutmainnah, Nidaul Islam \\ IAIN Parepare \\ e-mail: $\underline{\text { baru@stainparepare.ac.id }}$
}

\begin{abstract}
Abstrak
Studi artikel ini menjelaskan tentang perilaku komunikasi anggota keluarga setelah adanya kehadian gadget. Pada perkembangan teknologi saat ini, gadget menjadi alat yang tidak dipisahkan oleh manusia dalam kehidupan sehraihari. Begitu pula, dengan anggota keluarga tidak bisa terlepas dengan gaget untuk mendukung aktifitas kesehariannya. Komunikasi merupakan kunci keharmonisan keluarga, namun kehadiran gadget memberikan pengaruh terhadap perilaku komunikasi keluarga. Artikel ini menggunakan metode penelitian kualitatif dengan pengumpulan data observasi, wawancara mendalam, dan data pendukung penelitian lainnya. hasil penellitian ini menemukan bahwa perilaku komunikasi anggota keluarga dalam menggunakan gadget terbagi dua yaitu proaktif dalam komuniikasi, dan reaktif dalam komunikasi keluarga. Komunikasi keluarga dalam mempertahankan keharmonisan ditunjukkan dengan berjalannya fungsi orang tua dalam mendidik dan selalu memberikan perhatian pada anaknya, baik dengan komunikasi langsung maupun melalui gadget. Sehingga, keluarga tetap harmonis karena komunikasi keluarga tetap berjalan walaupun adanya kehadiran gadget.
\end{abstract}

Kata Kunci: Komunikasi, Gadget, Keluarga

Abstract

The study of this article explains the communication behavior of family members after the onset of the gadget. In the current technological development, gadgets become tools that are not separated by humans in everyday life. Similarly, with family members can not be separated with gaget to support their daily activities. Communication is the key to family harmony, but the presence of gadgets has an influence on family communication behavior. This article uses qualitative research methods by collecting observation data, in-depth interviews, and other research supporting data. the results of this study found that the communication behavior of family members in using gadgets is divided into two, namely proactive in communication, and reactive in family communication. Family communication in maintaining harmony is shown by the 
functioning of parents in educating and always paying attention to their children, either by direct communication or through gadgets. Thus, the family remains harmonious because family communication continues despite the presence of a gadget.

Keywords: Communication, Gadgets, Family

\section{PENDAHULUAN}

Gadget memiliki banyak varian seperti handphone, Tab, dan laptop. Seiring pesatnya perkembangan teknologi, gadget kini memiliki banyak model dan fungsi. Selain sebagai sarana media komunikasi, gadget juga digunakan jadi hiburan dan membantu ekfektivitas pekerjaan. Hingga kini, gadget sudah menjadi kebutuhan pokok masyarakat. Dalam setiap tempat sudah dipenuhi oleh pengguna gadget. Mulai dari rumah, pasar, sekolah, tempat kerja, kampus bahkan di kendaraan sekalipun sudah memakai gadget.

Keutamaan gadget adalah sebagai alat komunikasi seperti handphone dan tab. Selebihnya digunakan untuk mengentik dan membuat laporan melalui program Microsoft World di laptop atau komputer. Komunikasi semakin mudah dengan hadirnya handphone. Kemampuan berinteraksi dan berkomunikasi adalah salah satu ciri khas manusia yang membedakannya dari makhluk-makhluk yang lain. Dalam berkomunikasi manusia menggunakan bahasa untuk mengungkapkan ide dan gagasannya. Di Indonesia terdapat tiga jenis bahasa, yakni bahasa Indonesia, bahasa daerah, dan bahasa asing. Ketiga bahasa tersebut memiliki kedudukan dan fungsinya masing-masing. Bahasa Indonesia berkedudukan sebagai bahasa nasional dan bahasa negara. Kedudukan bahasa Indonesia sebagai bahasa nasional dimulai sejak diikrarkannya Sumpah Pemuda pada tanggal 28 Oktober 1928. Sedangkan sebagai bahasa negara tercantum dalam UndangUndang Dasar 1945, Bab XV, pasal 36. Sebagai bahasa negara, bahasa Indonesia berfungsi sebagai; (1) bahasa resmi kenegaraan, (2) bahasa pengantar resmi di lembaga-lembaga pendidikan, (3) sarana perencanaan dan pelaksanaan pembangunan serta pemerintahan, dan (4) sarana pengembangan kebudayaan dan 
pemanfaatan ilmu pengetahuan serta teknologi modern. Sedangkan sebagai bahasa nasional, bahasa Indonesia berfungsi sebagai; (1) identitas nasional, (2) kebanggaan bangsa, (3) alat komunikasi, dan (4) alat pemersatu bangsa yang berbeda suku, agama, ras, adat istiadat, dan budaya.

Pesatnya perkembangan teknologi membuat gadget juga berubah menjadi semakin canggih. Dalam hal ini, seperti gadget berupa handphone yag dulunya hanya bisa menelpon dan sms. Hingga sekarang ini, handphone sudah banyak berubah bentuk menjadi smartphone. Dalam smartphone sendiri, memiliki banyak aplikasi dalam berupa media sosial. Media sosial dalam hal ini seperti facebook, whats up, line, dll. Adapun data yang menunjukkan penggunaan smartphone beradasar pada umur yaitu:

\section{Age Distribution, Smartphones versus Tablets}
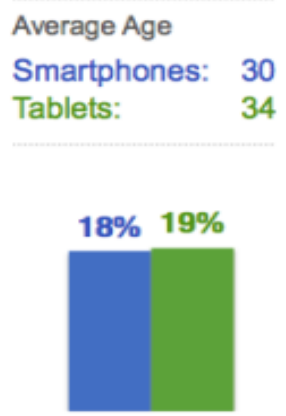

$13-17$

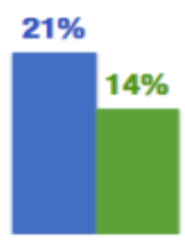

$18-24$

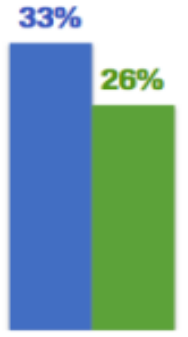

$25-34$

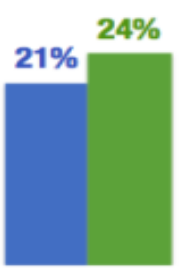

$35-54$

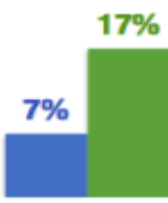

$55+$

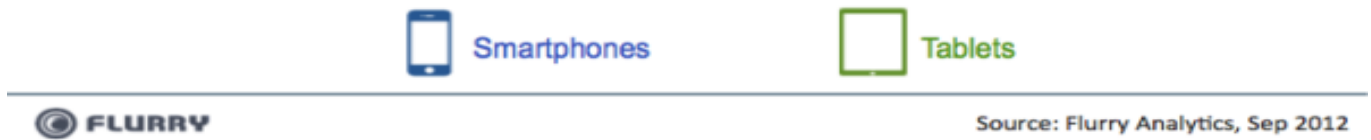

Gambar 1. Data Pengguna Smartphone dan Tab Berdasarkan Usia (https://inovasicom.files.wordpress.com).

Dari gambar diatas menunjukkan bahwa usia pengguna baik muda maupun tua sudah menggunakan smartphone dan tab. Gadget yang sebagian besar digunakan sebagai alat komunikasi dan media sosial yang disebabkan oleh aktualisasi diri bagi para penggunanya. Hal tersebut juga didukung oleh penelitian kualitatif dari Novitasari (http:ejournal.unesa.ac.id). Menemukan hasil yang serupa yaitu terdapat 5 (lima) pemaknaan dalam penggunaan jejaring sosial path. 
Pertama, sebagai eksistensi diri dari berbagai kegiatan yang diunggah ke dalam jejaring sosial path. Kedua, makna aktualisasi diri yang berorientasi kepada tujuan akan dicapai. Ketiga, makna informasi dari berbagai aktivitas yang diunggah ke dalam jejaring sosial path mampu memberikan informasi terhadap pengguna lainnya. Keempat, makna hiburan yang didapatkan dari aktivitas mengunggah berbagai macam gambar lucu serta kata-kata motivasi dan yang terakhir kelima, makna komunikasi dan menjalin silahturahmi melalui berbagi komentar dengan sesama pengguna jejaring sosial path. Selain itu gadget berupa laptop dan komputer dulunya hanya bisa digunakan untuk bekerja. Pada masa sekarang ini sudah memiliki koneksi melalui internet dapat membantu pekerja untuk berkomunikasi.

Gadget yang awalnya memiliki banyak manfaat terutama untuk komunikasi mulai memiliki sisi negatif bagi penggunanya. Pengguna gadget mulai menghabiskan waktu dengan gadgetnya dari pada berinteraksi atau sekedar bercengkrama disekitarnya terutama keluarganya sendiri. Hal ini mengubah pola hubungan interaksi keluarga yang seharusnya ketika di rumah bisa berkumpul bersama keluarga dan bercengkrama. Namun, yang terjadi malah sebaliknya yaitu masing-masing anggota sudah sibuk dengan kegiatan bersama gadgetnya masingmasing. Hal ini didukung oleh tulisan Bungin (2006) bahwa interaksi sosial yang menggunakan media (gadget) pasti juga akan mengubah pola hubungan interaksi anggota-anggotanya. Sementara itu, cita-cita keluarga seharusnya harmonis tidak akan tercapai bila interaksi antar setiap anggota berkurang yang disebabkan kesibukan menggunakan gadget masing-masing. Hal ini dikemukakan oleh Daradjad (2009) bahwa keharmonisan keluarga merupakan kondisi dimana anggota keluarga menjadi satu dan setiap anggota terjalin kasih sayang, saling pengertian, dialog dan kerjasama yang baik. Dengan demikian, untuk membuktikan pengaruh gadget terhadap kaharmonisan keluarga diperlukan data penelitian untuk mendukungnya. Dalam hal ini, penelitian akan menulusuri lebih Bagaimana cara anggota keluarga mempertahankan kahrmonisan keluarga mereka dengan kehadiran gadget?. 


\section{PEMBAHASAN}

\section{Konsep Komunikasi Keluarga}

Keluarga merupakan sistem lembaga sosial terkecil dalam keluarga yang memiliki aturan dan kebiasaan. Setiap anggota keluarga terdapat interaksi antara orang tua dan anak agar lembaga ini bisa berjalan dengan baik. oleh karena itu komunikasi dalam keluarga sangat diperlukan dalam hal ini. Menurut Effendy (Stanley J. Baran, 2012:5), komunikasi adalah suatu proses dalam menyampaikan pesan dari seseorang kepada orang lain dengan bertujuan untuk memberi tahu, mengeluarkan pendapat, mengubah pola sikap atau perilaku baik langsung maupun tidak langsung. R. Wayne Pace (1979) mengemukakan bahwa komunikasi antarpribadi atau communication interpersonal merupakan proses komunikasi yang berlangsung antara dua orang atau lebih secara tatap muka dimana pengirim dapat menyampaikan pesan secara langsung dan penerima pesan dapat menerima dan menanggapi secara langsung. Komunikasi interpersonal merupakan komunikasi yang pesannya dikemas dalam bentuk verbal atau nonverbal, seperti komunikasi pada umumnya komunikasi interpersonal selalu mencakup dua unsur pokok yaitu isi pesan dan bagaimana isi pesan dikatakan atau dilakukan secara verbal atau nonverbal. Dua unsur tersebut sebaiknya diperhatikan dan dilakukan berdasarkan pertimbangan situasi, kondisi, dan keadaan penerima pesan.

Adapun intensitas komunikasi menurut Devito bahwa intensitas komunikasi individu dapat ditinjau dari enam aspek, yaitu:

\section{Frekuensi Berkomunikasi}

Frekuensi disini berarti tingkat kekerapan atau keseringan dalam berkomunikasi, tingkat keseringan orag tua dengan anaknya melakukan aktivitas komunikasi. Dalam hal ini, seperti tingkat kekerapan melakukan komunikasi disini dilakukan dalam satu minggu 3 kali atau dalam satu bulan sebanyak 4 kali, dsb. 


\section{Durasi yang digunakan untuk berkomunikasi}

Durasi disini berarti lamanya waktu atau rentang waktu yang digunakan pada saat melakukan aktivitas komunikasi. Lamanya waktu yang digunakan bisa bervariasi, misalkan dalam satu kali bertemu lamanya waktu yang digunakan bisa menapai 2-3 jam dan atau mungkin bisa lebih dari itu atau bisa berkurang.

\section{Perhatian yang diberikan saat berkomunikasi}

Perhatian yang diberikan saat berkomunikasi diartikan sebagi fikus yang dicurahkan oleh partisipan komunikasi saat berkomunikasi. Perhatian disini mengarah pada pemusatan seluruh tenaga yang mengiringi aktivitas orang tua yang secara sadar ditujukan pada anaknya yang memperoleh hasil belajar yang optimal.

\section{Keteraturan dalam berkomunikasi}

Keteraturan disini berarti kesamaan sejumlah keadaan, kegiatan atau proses yang terjadi beberapa kali atau dalam melakukan aktivitas komunikasi yang dilakukan secara rutin dan lentur.

Tingkat keluasan pesan komunikasi \& jumlah orang yang diajak berkomunikasi

\section{Tingkat kedalaman komunikasi}

Tingkat kedalaman komunikasi berupa kejujuran, keterbukaan, dan sikap saling percaya antar partisipan saat berkomunikasi.

\section{Perilaku Komunikasi Keluarga}

Perilaku manusia memiliki berbagai macam bentuk, yang didalamnya bisamenyangkut pada perilaku sosial, perilaku individu ataupun perilaku ketikamelakukan kegiatan tertentu. Dalam penelitian ini, akan lebih memfokuskan pembahasan pada perilaku komunikasi antar sesama anggota keluarga. Hal tersebut dihubungkan pada komunikasi antar pribadi yaitu: 
a. Keterbukaan (Openess)

Kualitas keterbukaan mengacu pada tiga aspek antar pribadi. Pertama, komunikator antar pribadi yang effektif harus terbuka kepada orang yang diajknya berinteraksi. Aspek keterbukaan yang kedua mengacu pada kesediaan komunikator untuk beraksi secara jujur terhadap stimulus yang datang. Aspek ketiga menyangkut "kepemilikan" perasaan dan pikiran. Terbuka dalam pengertian ini adalah mengakui bahwa perasaan dan pikiran yang anda lontarkan adalah emmang "milik" Anda dan Anda bertanggung jawab atasnya.

b. Empati (Empathy)

Henry Backrack mendefinisikan empati sebagai "kemampuan seseorang untuk 'mengetahu' apa yang sedang dialami orang lain pada saat tertentu, dari sudut pandang orang lain itu, melalui kacamata orang lain.

c. Sikap Mendukung (Supportiveness)

Hubungan antar pribadi yang efektif adalah hubungan dimana terdapat sikap mendukung (supportiveness)-suatu konsep yang perumusannya dilakukan beradasrkan karya Jack Gibb. Komunikasi yang terbuka an empati tidak dapat berlangsung dalam suasana yang mendukung. Kita melibatkan sikap mendukung dengan bersikap (1) deskriptif, bukan evaluatif; (2) spontan, bukan strategi, dan (3) proposional, bukan sangat yakin.

d. Sikap positif (Positiveness)

Kita mengkomunikasikan sikap positif dalam komunikasi antarpribadi dengan sedikitnya dua cara : (1) menyatakan sikap positif dan (2) seccara positif mendorong orang yang menjadi temn kita berinteraksi.

e. Kesetaraan (Equality)

Dalam setiap stuasi, barangkali terjadi ketidaksetaraan. Terlepas dari ketidaksetaraan ini, komunikasi antarpribadi akan lebih efektif bila suasananya setara. Artinya, hatus ada pengakuan secara diam-diam bahwa kedua belah pihak sama-sama bernilai dan berharga dan bahwa masingmasing pihak mempunyai sesuatu yang penting untuk disumbangkan. 


\section{Gadget}

Gadget berasal dari bahasa Inggris dengan arti perangkat elektronik kecil yang memiliki fungsi khusus. Dalam tulisan Widiawati dan Sugiman (2004), gadget adalah barang canggih dengan berbagai aplikasi yang dapat menyajikan berbagai berita media, jejaring sosial, hobi bahkan hiburan. Menurut Wikipedia Gadget "A gadget is a small tool such as a machine that has a particular function, but is often thought of as a novelty. Gadgets are invariably, considered to be more unusually or cleverly designed than normal 14 tools at the time of their invention. Gadgets are sometimes referred to as gizmos.

Hal tersebut menjelaskan bahwa gadget merupakan sebuah benda kecil dengan piranti yang menggunakan partikel kecil dan memiliki teknologi tinggi yang selalu diperbaharui dan beinovasi. Gadget tidak hanya berupa handphone, akan tetapi gadget juga berkembang dalam bentuk tablet, dvd, ipad, windows, notebook (perpaduan antara komputer portabel seperti notebook dan internet), kamera digital, dsb.

\section{Keluarga}

Keluarga adalah lingkungan dimana beberapa orang yang masih memiliki hubungan darah dan bersatu. Keluarga didefinisikan sebagai sekumpulan orang yang tinggal dalam satu rumah yang masih mempunyai hubungan kekerabatan/hubungan darah karena perkawinan, kelahiran, adopsi dan lain sebagainya. Keluarga yang terdiri dari ayah, ibu dan anak-anak yang belum menikah disebut keluarga batih. Sebagai unit pergaulan terkecil yang hidup dalam masyarakat, keluarga batih mempunyai peranan-peranan tertentu, yaitu a) Keluarga batih berperan sebagi pelindung bagi pribadi-pribadi yang menjadi anggota, dimana ketentraman dan ketertiban diperoleh dalam wadah tersebut; b) Keluarga batih merupakan unit sosial-ekonomis yang secara materil memenuhi kebutuhan anggotanya; c) Keluarga batih menumbuhkan dasar-dasar bagi kaidahkaidah pergaulan hidup; d) Keluarga batih merupakan wadah dimana manusia mengalami proses sosialisasi awal, yakni suatu proses dimana manusia mempelajari dan mematuhi kaidah-kaidah dan nilai-nilai yang berlaku dalam masyarakat. 


\section{Keharmonisan Keluarga}

Keluarga merupakan struktur sosial terkecil dalam masyarakat. Seseorang dapat tumbuh dan berkembang dengan baik jika mereka tumbuh dalam keluarga yang harmonis. Gunarsa (2003) menjelaskan bahwa yang dimaksud dengan keluarga harmonis adalah bilamana seluruh anggota keluarga merasa bahagia yang ditandai oleh berkurangnya ketegangan, kekecewaan dan menerima seluruh keadaan dan keberadaan dirinya (eksistensi, aktualisasi diri) yang meliputi aspek fisik, mental.

Sementara itu menurut menurut Inggrid (2004) keluarga yang harmonis adalah keluarga yang dapat mengantarkan seseorang hidup lebih bahagia, lebih layak dan lebih tentram. Keluarga merupakan tempat para penghuninya beristirahat dari suatu kepenatan aktivitas, sehingga keluarga haruslah menyenangkan. Hal tersebut didukung oleh Nick (2002), keluarga harmonis merupakan tempat yang menyenangkan dan positif untuk hidup, karena anggotanya telah belajar beberapa cara untuk saling memperlakukan dengan baik. Anggota keluarga dapat saling mendapatkan dukungan, kasih sayang dan loyalitas. Mereka dapat berbicara satu sama lain, mereka saling menghargai dan menikmati keberadaan bersama.

Kartono (2004:48) menjelaskan bahwa aspek-aspek keharmonisan di dalam keluarga seperti adanya hubungan atau komunikasi yang hangat antar sesama anggota keluarga, adanya kasih sayang yang tulus dan adanya saling pengertian terhadap sesama anggota keluarga. Sementara Menurut Gunarsa (2000:50) ada banyak aspek dari keharmonisan keluarga diantaranya adalah:

a. Kasih sayang antara keluarga. Kasih sayang merupakan kebutuhan manusia yang hakiki, karena sejak lahir manusia sudah membutuhkan kasih sayang dari sesama. Dalam suatu keluarga yang memang mempunyai hubungan emosianal antara satu dengan yang lainnya sudah semestinya kasih sayang yang terjalin diantara mereka mengalir dengan baik dan harmonis.

b. Saling pengertian sesama anggota keluarga. Selain kasih sayang, pada umumnya para remaja sangat mengharapkan pengertian dari orangtuanya. Dengan 
adanya saling pengertian maka tidak akan terjadi pertengkaran-pertengkaran antar sesama anggota keluarga.

c. Dialog atau komunikasi efektif yang terjalin di dalam keluarga Anggota keluarga mempunyai keterampilan berkomunikasi dan banyak waktu digunakan untuk itu.

d. Mempunyai waktu bersama dan kerjasama dalam keluarga Keluarga menghabiskan waktu (kualitas dan kuantitas waktu yang besar) di antara mereka. Kebersamaan di antara mereka sangatlah kuat, namun tidak mengekang. Selain itu, kerjasama yang baik antara sesama anggota keluarga juga sangat dibutuhkan dalam kehidupan sehari-hari. Saling membantu dan gotong royong akan mendorong anak untuk bersifat toleransi jika kelak bersosialisasi dalam masyarakat.

Penelitian ini akan dilakukan dengan pendekatan metode penelitian kualitatif. Srategi penelitian memungkinkan terjadinya dialog peneliti dan tineliti, sehingga kebenaran adalah kesepahaman bersama atas sebuah masalah berupa intersubyektifitas yang lahir akibat interaksi antara peneliti dan tineliti.

Penelitian ini akan memerlukan data dari kelompok sampel yang terdiri dari rumah tangga berdasarkan RT dari Kelurahan. Pengambilan sampel rumah tangga dilakukan dengan menggunakan metode pengambilan sampel yang disengaja atau sudah ditentukan (purposive sampling). Metode pengambilan sampel ini digunakan karena (1) biaya relatif rendah, (2) penggolongan ke dalam sub populasi dapat meningkatkan posisi nilai-nilai dugaan dan ciri-ciri populasi yang dapat diukur, dan (3) secara administratif mudah.

\section{Perilaku Anggota Keluarga dalam Melakukan Komunikasi Keluarga}

Komunikasi keluarga memiliki peranan penting dalam menopang kedekatan hubungan antar anggotanya. Anak-anak yang tumbuh karena kedekatan komunikasi antara orang tua dan anak memiliki tingkat pertumbuhan kedewasaaan yang matang baik secara fisik, emosional maupun intelektual. Begitu pula, anak-anak yang tidak memiliki kedekatan emosional dengan orang 
tua yang disebabkan oleh komunikasi yang kurang antara anak dan orang tua. Hal tersebut dapat menyebabkan anak menjadi kurang matang dalam kedewasaannya.

Peran keluarga mulai dari orang tua sebagai pendidik dan pembimbing sangat penting untuk mengenalkan nilai-nilai kehidupan kepada anak. Mereka bertanggug jaab atas pembentukan sikap dan karakter anak. Termasuk, informasi yang diterima anak dalam proses tumbuh kembangnya, baik melalui gagdet internet, maupun dari lingkungannya secara langsung. Namun, hal tersebut bisa terjadi jika adanya inisiatif antar anggota keluarga untuk mau melakukan komuikasi. Dalam hal ini, sikap proaktif ataupun reaktif dari anggota keluarga dalam melakukan komunikasi melalui gadget. Proaktif yang dimaksud ialah anggota keluarga mampu secara terbuka mengungkapkan bentuk komunikasi apa saja yang telah mereka lakukan melalui gadget. Serta, bersedia menerima feedback dari keluarga dalam setiap komunikasi yang dilakukan. Adapun sikap reaktif dalam komunikasi melalui gadget ialah sikap tertutup, tidak mau mengungkapkan informasi ataupun komunikasi yang dilakukan melalui gadget.

\section{Perilaku Proaktif Komunikasi Keluarga dalam Penggunaaan Gadget}

Perilaku proaktif dapat ditunjukkan melalui keaktifan seseorang untuk melakukan suatu perubahan terhadap dirinya sendiri, maupun perilaku yang bermanfaat pada lingkungannya. Keluarga informan JS (46 tahun) memiliki 1 istri, dan 3 orang anak. Anak pertama mereka sudah menduduki bangku SMA, sementara yang paling bungsu masih berumur 5 tahun. Anak pertama dan anak kedua JS diberikan fasilitas gadget berupa smartphone, televisi, dan laptop. JS memberikan fasilitas gadget smartphone tersebut untuk memudahkan komunikasi, mencari tugas sekolah melalui internet, dan laptop digunakan untuk mengerjakan tugas. Sementara televisi digunakan untuk menonton. Berikut kutipan wawancaranya (JS, 2 Oktober 2019):

"Saya memang sengaja memberikan smartphone dan fasilitas internet kepada anak saya, dengan harapan setiap mereka kerja tugas tinnggal mencari jawabannya melalui internet. Selain itu utuk memudahkan mengetahui posisi anak saya ketika sedang berada di luar rumah”. 
Pak JS berupaya agar anaknya bisa menggunakan internet secara positif. Dalam hal ini, dia ingin anaknya secara mandri menggunakan fasilitas tersebut agar kegunaannya tidak melenceng dari yang semestinya. JS dalam pekerjaan sehari-harinya sebagai pegawai negeri sipil di kantor kelurahan. Ketika pulang kerja, JS selalu menyempatkan waktunya untuk berdiskusi dengan anaknya. Sebagai orang tua, beliau selalu berinisiatif untuk melakukan komunikasi dahulu dengan anaknya. Selebihnya, lebih banyak waktu yang dia habiskan untuk pergi main handphone atau main domino bersama tetangganya. Pertemuan anggota keluarga untuk duduk bersama dalam satu waktu dan kesempatan sangat penting sebagai symbol keakraban keluarga. Moment seperti waktu makan, menonton televise, duduk santai, ketika anak sedang bermain-main di dalam rumah, dapat dimanfaatkan oleh orang tua untuk bercengkrama, bersenda gurau atau membicarakan hal-hal yang bermanfaat bagi kebaikan anggota keluarga untuk menjalin hubungan yang akrab dalam keluarga tidak mesti harus diawali dengan pertemuan formal.

Pertemuan informal juga memiliki nilai strategis dalam mengakrabkan hubungan orang tua dengan anak. Bahkan terkadang via pertemuan informal pesan-pesan kebaikan dapat tersalur secara efektif. Ketika anak-anak duduk bersama antar sesama mereka, orang tua harus pandai memanfaatkan moment tersebut untuk duduk bersama mereka, memahami mereka, bermain bersama mereka, berbicara dan berdialog yang disesuaikan dengan tingkat berfikir dan dunia anak-anak. Di sini orang tua harus produktif untuk mengawali pembicaraan. Jangan paksa anak untuk memahami dunia orang tua, berfikir dan berprilaku seperti orang tua. Jika hal itu terjadi, maka komunikasi antara orang tua dan anak tidak dapat berlangsung baik dan efektif. Akhirnya, sudah waktunya orang tua meluangkan waktu dan kesempatan untuk duduk bersama dengan anak- anak, berbicara, berdialog dalam suasana santai.

Informan AN (35 tahun) seorang ibu rumah tangga, memiliki anak yang sedang kuliah di Perguruan Tinggi di kota Makassar. Komunikasi yang terbangun melalui gadget berupa handphone hampir selalu dia lakukan. Inisiatif komunikasi dilakukan secara bergantian, baik ibu AN yang lebih dahulu meghubungi ataupun anaknya yang dahulu menghubunginya. Berikut kutipan wawancara dengan Ibu AN (Wawancara, tanggal 5 Oktober 2019): 
"Saya bisa dibilang tiada hari tanpa handphone, karena kalau mau bicara sama anakku cuma bisa pake hp. Kasian jauh anakku, jadi harus selalu dipantau. Biasa kalau kutelpon kutanya sudah makan nak, masih ada berasmu, uangmu masih cukup, dan sebagainya. Kadang juga anakku yang telponka duluan kalau ada yang dia butuhkan"

Perilaku proaktif orang tua melalui perhatian dan kasih sayang orang tua kepada anak yang jauh dirantau dapat dilakukan dengan komunikasi melalui gadget. Anak berperilaku proaktif dengan melakukan komunikasi dengan orang tua hanya ketika butuh sesuatu. Dalam artian, perilaku proaktif orang tua kepada anak lebih merujuk pada perasaaan empati, kasih sayang, perhatian, sikapa mendukung, dan keterbukaan. Sementara anak berperilaku proaktif dalam keluarga ketika menginginkan suatu keutuhan kepada orang tua. Perkembangan abad informasi digital dan cyberspace dewasa ini telah merubah potret keluarga, khususnya yang tinggal di perkotaan. keluarga harmoni, sebgai sumber informasi dan sosialisasi telah bergeser menjadi keluarga digital. Perkembangan teknologi informasi dan komunikasi global deassa ini telah menelan berbagai dimensi keluarga (Prasanti Ditha:77). Melalui perkembangan berbagai bentuk teknologi informasi dan komunikasi yang bersifat segera (instantaneous), cepat, dan virtual, maka interaksi, relasi yang diperantarai oleh media sosial (Piliang, Yasraf Amir, 2004).

\section{Perilaku Reaktif Komunikasi Keluarga dalam Penggunaan Gadget}

Perilaku reaktif komunikasi keluarga muncul karena disibukkan oleh kehadiran gadget. teknologi informasi dan komunnikasi mengakibatkan perubahan media komunikasi yang berpotensi bagaimana anak di era milenium memiliki karakteristik yang jauh berbeda dari generasi sebelumnya. Kerenggangan hubungan sosial antara orang dan anak dipicu oleh kesibukan masing-masing dengan gadgetnya (Pebriana, 2017:1). Seperti wawancara dengan informan AC (46 tahun) sekarang menjabat sebagai ketua RT di kelurahan Watang Soreang, dalam wawancara dia menyebutkan sebagai berikut (Wawancara 7 Oktober 2019) : 
"anak saya satu laki-laki masih SMP, dan 2 lainnya perempuan. Yang laki-laki itu tiada hari tanpa pegang hp. Ituji klu ke sekolahnya baru dia lepas hpnya. Tapi klu pulangmi dari sekolah, main game terusmi dengan hpnya. Biasa kumarahi, kubilang tidak adakah tugas sekolahmu, tapi tetapji dia bikin (bermain hp").

Sebagai orang tua, AC merasa bertanggung jawab terahadap perilaku anaknya yang sudah kecanduan bermain handphone. Setelah ditelusuri, dengan mawawancarai anak AC, ternyata game yang membuat dia kecanduan adalah Mobile Legend ${ }^{1}$. Ketergantungan anak dalam bermain gadget, membuat perubahan pada hubungan sosial yang mereka miliki. Ketidakinginan untuk bersosialisasi baik dengan keluarga maupun dengan lingkungan masyarakat disekitarnya. Hal tersebut, menjadi pertanda bahwa mereka kehilangan keinginan untuk beraktivitas selain main gadget dan cenderung sering membantah suatu perintah jika itu menghalanginya untuk bermain gadget.

Dalam hal ini, gadget memiliki pengaruh pada perilaku reaktif anak baik yang masih usia dini maupun usia dewasa. Perilaku reaktif ditandai dengan kurangnya komunikasi dengan orang tua dalam bentuk sifat acuh, mudah membangkanng serta sudah tidak mendengar nasihat orang tua mengenai pentingnya mengatur waktu dalam penggunaan gadget.

\section{Keharmonisan Keluarga dalam Penggunaan Gadget}

Kondisi keluarga yang harmonis ditandai dengan suatu bentuk komunikasi yang baik antara orangtua dengan anak, bapak dengan ibu dan antara anak dengan saudaranya.

Tak dapat dipungkiri, kehadiran gadget membawa sebuah perubahan pada pola komunkasi keluarga. Dalam hal ini, sebagian besar anggota keluarga menghabiskan wakunya untuk bermain gadget. Fasilitas hiburan yang lengkap melalui gadget seperti media sosial, berita terkini, game online membuat orangorang tidak bisa hidup tanpa gadget. Selain itu, untuk mendukung pekerjaan sekolah ataupun pekerjaan kantor juga membutuhkan gadget berupa laptop. Seperti yang dikemukakan oleh WR (Wawancara, 23 Oktober 2018):

${ }^{1}$ Mobile Legend adalah satu aplikasi game online yang bisa diunduh di Play Store Smartphone. 
"Saya kerja di finance, jadi selalu pakai hp untuk hubungi customer. Setiap hari tidak bisa lepas dari hp. Bahkan, sampai d rumah harus kembali lagi ke kantor untuk urusan kerja. Waktu bersama keluarga tergantung dari selesainya pekerjaan. Anak saya masih kecil, walau hanya bermain sama-sama sebentar, dia sudah senang. Istri yang paling sering menegur jika sudah terlalu banyak waktu dengan hp dan kerjaan"

Wawancara tersebut menggambarkan bahwa komunikasi keluarga penting untuk menciptakan kehidupan bersama dan memperat keterikatan antar anggota keluarga. Pada dasarnya anggota keluarga hanya perlu saling memahami kebutuhan pentingnya komunikasi walaupun disibukkan dengan gadget dan pekerjaan.

Pada pembahasan sebelumnya, intensitas komunikasi antar anggota keluarga dengan menggunakan gadget masih kurang dibanding komunikasi dengan media sosial. Komunikasi lewat gadget digunakan hanya untuk memastikan kondisi anggota keluarga dalam keadaan baik-baik saja. Seperti informan NN (Wawancara, 27 Oktober 2019):

"Saya sering telpon bapak (suami) untuk tanya kapan pulang, minta diibelikan sesuatu kalau lagi diluar. Paling sering itu suruh cepat pulang, karena saya tidak mau kalau suamiku pergi sembarag tempat. Kadang, jengkel juga suamiku, tapi kalau tidak dikasih begitu tidak cepatki pulang ke rumah. Anakku juga kalau terlambat pulang pasti saya telpon hpnya, suruh cepat pulang"

Informan NN merasa terbantu dengan kehadiran gadget berupa hadnphone. Dengan alasan, lebih memudahkan dia untuk berkomunikasi dengan suami dan anak yang tidak sedang di rumah. NN juga kadang curiga dengan suami apabila terlambat pulang, akan tetapi suami NN terbuka dalam memberikan setiap informasi kepada istrinya tidak curiga. Bahkan, dia tidak mengunci atau privasi handphone yang dia pegang kepada istrinya. Sehingga, istrinya bisa dengan bebas mengecek handphonenya, dengan siapa dia berkomunikasi. Hal tersebut membuat NN masih harmonis hingga sekarang ini karena keterbukaan komunikasi dengan anggota keluarga, saling mennghargai, dan bisa menyelesaikan masalah dengan baik walaupun anggota keluarga memiliki kesibukan masing-masing.

Bila pola pengasuhan anak tidak tepat, maka hal itu akan berdampak pada pola perilaku anak. Apalagi jika anak meniru perilaku orang-orang di luar rumah 
yang cenderung negatif. Pola pengasuhan yang intens akan membentuk jalinan hubungan kuat di antara orang yang diidentifikasi dan orang mengidentifikasi (anak dengan orang yang membimbing). Dengan demikian, anak yang benarbenar melakukan identifikasi cenderung mencari figur yang dapat diterima dan sesuai dengan proses pembentukan dirinya.

Adapun mereka yang telah terbebas dari beban dan tekanan diri dan lingkunganya akan dengan mudah menjalankan proses identifikasi yang sesuai dengan kemampuan dan potensi dirinya. Dari keterangan di atas dapat dipahami bahwa pengasuhan anak menjadi takap penting dalam membentuk karakter, moralitas, pengetahuan, keterampilan, dan life skill yang memadai bagi anak. Oleh sebab itu, kerja sama semua agen sosialisasi baik keluarga, sekolah, dan masyarakat menjadi solusi terbaik demi suksesnya anak. Khusus bagi keluarga, tugas dan tanggung jawab dalam menyukseskan pengasuhan anak sejak dini sangat besar, mengingat dari keluargalah seorang anak lahir dan berkembang. Pola asuh dan lingkungan keluarga sangat menentukan pola pikir, kebiasaan, dan kemampuan memotret kehidupan dunia yang penuh kompetisi, aktualitas, dan dinamika. Adapun beberapa definisi tentang pengasuhan tersebut menunjukkan bahwa pengasuhan anak merupakan sebuah proses interaksi yang terus menerus antara orangtua dengan anak yang bertujuan untuk mendorong pertumbuhan dan perkembangan anak secara optimal, baik secara fisik, mental maupun sosial.

Dalam hal ini perlu diingat bahwa proses interaksi dan sosialisasi tidak dapat dilepaskan dari setting sosial budaya tempat anak dibesarkan. Pola asuh orangtua merupakan segala bentuk dan proses interaksi yang terjadi antara orangtua dan anak yang dapat memberi pengaruh terhadap perkembangan kepribadian anak. Interaksi orang tua dalam suatu pembelajaran menentukan karakter anak nantinya.

\section{SIMPULAN}

Pada zaman serba teknologi sekarang ini, gadget menjadi barang yang tidak terpisahkan oleh manusia. Gadget dapat berupa laptop, televisi, komputer, handphone, dan sebagainya. Gadget yang paling sering dipakai ialah laptop dan 


\section{A. Mutmainnah, Nidaul Islam, Penggunaan Gadget terhadap...}

hadnphone. Laptop merupakan alat yang dipakai untuk memudahkan pekerjaan sekolah dan kantor. Sementara, handphone ditujukan untuk memudahkan komunikasi. Namun, seiring perkembangan zaman, laptop dan handphone mengalami peningkatan aplikasi program. Handphone sekarang ini berubah dalam bentuk smartphone yang dilengkapi dengan berbagai aplikasi untuk media komunikasi. Seperti media sosial berupa facebook, instagram, Whatsupp, game online dan sebagainya. Dengan bermodalkan internet, sudah bisa berselancar di dunia maya lewat satu genggaman smartphone.

Kemudahan yang diberikan dari gagdet smartphone, ternyata memberikan dampak bagi perilaku komunikasi penggunanya. Khususnya perilaku komunikasi terhadap sesama anggota keluarga. Perilaku proaktif komunikasi keluarga dalam menggunakan gagdet ditandai dengan inisiatif antar anggota keluarga untuk meluangkan waktunya melakukan komunikasi. Dalam artian, gadget membantu untuk mereka berkomunikasi dengan keluarga baik jarak dekat maupun jarak jauh atau beda tempat. Mereka yang proaktif dalam berkomunikasi dalam keluarga ialah orangtua. Orangtua memiliki peran sangat penting untuk berjalannya komunikasi di keluarga. Perhatian orangtua baik secara langsung maupun melalui gadget pada anggota keluarga memiliki pengaruh terhadap keberlangsungan komunikasi antar anggota keluarga. Berbeda dengan anggota keluarga dengan posisi sebagai anak yang memiliki perilaku reaktif dalam komunikasi keluarga menggunakan gadget. Mereka cenderung lebih memilih menggunakan gadget untuk bermain di media sosial, dan bermain game online dibanding berkomunikasi dengan sesama anggota keluarga. Komunikasi dengan anggota keluarga hanya seperlunya saja baik secara langsung maupun melalui gadget.

Anggota keluarga lebih memilih melakukan komunikasi melalui gadget dengan menggunakan media sosial dibanding komunikasi dengan anggota keluarga. Intensitas waktu yang dihabiskan untuk komunikasi gadget melalui media sosial yaitu 5 sampai 10 jam. Sementara, komunikasi gadget dengan keluarga hanya 1 sampai 5 jam. Hal tersebut megindikasikan bahwa masyarakat lebih memilih gadget untuk media sosial dibanding untuk komunikasi dengan keluarga. Namun, hal tersebut tidak membuat keharmonisan keluarga menjadi 
terganggu. Peranan orangtua untuk terus proaktif melakukan komunikasi dengan anak-anak menjadi kunci keharmonisan keluarga tetap langgeng. Selain itu, keterbukaan kunci antar suami, istri dan anak disetiap aktivitas dan berbagai permasalahan bisa terselesaikan. Sehingga, kesadaran komunikasi perlu ditingkatkan bukan hanya pada orang tua tapi juga untuk setiap anggota keluarga agar keharmonisan keluarga tetap terjaga walaupun dengan adanya kehadiran gadget.

\section{DAFTAR PUSTAKA}

Asriana, W., \& Ratnasari Y, Kecemburuan pada laki-laki dan Perempuan dalam Menghadapi Perselingkuhan Melalui Media Internet. Jurnal Psikologi Pitutur, Volume 1 No.1, Juni 2012, hlm 81-94

Bungin, Burhan. 2006. Sosiologi Komunikasi: Teori, Paradigma, dan Diskursus Daradjat, Zakiah. (2009). Ilmu Pendidikan Islam. Jakarta: Bumi Aksara.

Fitriawardhani Tira, Pemanfaatan Social Media Sebagai Sarana Komunikasi Keluarga Dalam Upaya Meminimalisir Perilaku Menyimpang Pada Masyarakat di Surabaya. Jurnal Litbang Kebijakan Cakrawala Jawwa Timur, Vol. 11 No.2 Desember 2017:hlm 181-194

Gunarsa, S. D. dan Yulia S. D. G. 2003. Psikologi Perkembangan Anak dan. Remaja. Jakarta: BPK

Inggrid. 2004. Manajemen Keluarga Sakinah. Yogyakarta: Diva Press https://inovasicom.files.wordpress.com/2012/11/flurry-smartpones-vs-tablets-byage-group.png. Diakses pada tanggal 14 Oktober 2018.

Maulana H, Gumelar G, Psikologi Komunikasi dan Persuasi, Bandung: Akademia Pustaka

Najoan Hardsen JI, Pola Komunikasi Suami Istri Dalam Menjaga Keharmonisai Keluarga Di Desa Toegesan II Kecamatan Kawangkoan Kabupaten Minahasa,e-journal "Acta lurna" Vol.4 Tahun 2015, hlm 5

Novitasari, M. 2014. Makna penggunaan jejaring sosial path bagi mahasiswa Unesa. Jurnal Vol 02 No 03. Diakses pada tanggal 21 Februari 2018 dari http: ejournal.unesa.ac.id/index.php/paradigma/article/ view/9082/12113.

Nick E. 2002. Psikologi Sosial Jilid 1. Edisi 10. (Diterjemahkan oleh Dra. Ratna Juwita), Jakarta: Dipl.Psychl. Erlangga

Widiawati, L., Sugiman, H., \& Edy (2204). Pengaruh penggunaan gadget terhadap daya kembang anak . Jakarta: Univerita Budi Luhur. 